\title{
The Relationship between Listening Strategies Used by Iranian EFL Freshman University Students and Their Listening Proficiency Levels
}

\author{
Farinaz Shirani Bidabadi (Corresponding author) \\ Faculty of Education, University Kebangsaan Malaysia, 43600 UKM Bangi, Malaysia \\ Tel: 60-17-686-1865 E-mail: F_sh3000@yahoo.com \\ Hamidah Yamat \\ Faculty of Education, University Kebangsaan Malaysia, 43600 UKM Bangi, Malaysia \\ Tel: 60-3-8921-6338Ｅ-mail: hya@ukm.my
}

\begin{abstract}
The purpose of the current study was to identify Iranian EFL freshman university students' listening proficiency levels and the listening strategies they employed to investigate the relationship between these two variables. A total of 92 freshmen were involved in this study. The Oxford Placement Test was employed to identify the learners' listening proficiency levels and a Listening Strategy Questionnaire was used to identify the strategies they employed in listening. The descriptive analysis of the listening strategy questionnaire revealed that Iranian EFL freshman university students at advanced, intermediate, and lower-intermediate levels employed meta-cognitive strategies more frequently and actively; followed by cognitive and socio-affective listening strategies. The Pearson Correlation analysis also indicated that there was a significant positive correlation between the listening strategies employed by advanced, intermediate, and lower-intermediate freshmen and their listening proficiency levels at $\mathrm{p}<0.01$ and $\mathrm{p}<0.05$ levels respectively.
\end{abstract}

Keywords: Listening strategy use, Listening proficiency levels, EFL, Freshman students

\section{Introduction}

Listening is an essential skill which develops faster than speaking and often affects the development of reading and writing abilities in learning a new language (Scarcella and Oxford, 1992; Oxford, 1993). This is because one receives input through listening to instructions or explanations prior to responding orally or in writing. Listening is also not an easy skill to be acquired because it requires listeners to make meaning from the oral input by drawing upon their background knowledge of the world and of the second language (Byrnes, 1984; Nagle \& Sanders, 1986; Young, 1997) and produce information in their long term memory and make their own interpretations of the spoken passages (Murphy, 1985; Mendelsohn, 1994; Young, 1997). In other words, listeners need to be active processors of information (Young, 1997). Meanwhile, Vandergrift (1996, 1997, and 2003) asserts that listening is a complex, active process of interpretation in which listeners try to suit what they hear with their prior knowledge. This process is more complex for second language learners who have limited memory capacity of the target language (Richards, 1983) thus requiring them to utilize various listening strategies. These strategies which have been developed based on O'Malley and Chamot's (1990) learning strategies were categorized as meta-cognitive, cognitive, and socio-affective strategies are steps taken to contribute learners to acquire, store, retrieve, and use information. Meta-cognitive strategies are employed by students to increase comprehension and second language retention, and include planning, monitoring, evaluating and problem-solving; cognitive strategies are utilized by listeners to cope with the material to be learned or to apply specific techniques, such as inferencing, repeating, deduction, imagery, elaboration, note taking, and translation; and socio-affective strategies are employed by language learners to cooperate with classmates, to question the teacher for clarification, or to apply specific techniques to lower anxiety (O'Malley, Chamot, \& Küpper, 1989; Vandergrift, 1997).

Despite, recognizing the importance of listening strategies for the development of foreign language proficiency, very limited studies have been performed in Iran concerning the strategies employed by Iranian EFL freshman university students in relation to listening proficiency levels. Therefore, this study sought to investigate the strategies employed by Iranian EFL freshman university students of three different listening proficiency levels (advanced, intermediate, and lower-intermediate). The study undertaken aimed to answer the following research questions: 1) what strategies do Iranian EFL freshman university students of three different listening proficiency levels employ while listening to a spoken text? 2) Is there a relationship between the strategies employed by Iranian EFL freshman university students and their English listening proficiency levels? 


\section{Listening Strategies and English Listening Proficiency}

Some researchers such as O'Malley, Chamot, and Kupper, (1989), Vandergrift (1997), Goh (2002), Vandergrift (2003) and Liu (2008) among others investigated the relationship between listening strategy employed by students and their listening abilities. They focused on mental processes of listeners (perception, parsing and utilization). They believe that more-proficient listeners are able to focus on what is being heard, to plan what to listen for, and to interact with both bottom-up and top-down processes; whereas less-proficient listeners would use predominately bottom-up processing, listening for single words, and utilizing strategies randomly (Liu, 2008). Similarly, Goh (2002) found that more proficient listeners use both cognitive and meta-cognitive strategies to achieve a meaningful interpretation of a text, and demonstrate the ability to use prior knowledge, linguistic cues, and contextual information. However, less proficient listeners are often distracted by unfamiliar lexis or expressions, and have a limited range of strategies.

Vandergrift (2003) investigated the relationship between listening proficiency and listening strategy used. A group of 36 junior high school students of French in Canada were recruited for listening strategy elicitations. The study showed that the more proficient listeners employed meta-cognitive strategies more frequently than the less proficient listeners, and the variations in this type of strategy use had a statistically significant relation across the listening ability.

Liu (2008) investigated 101 university male and female non-English major students at three universities in Taipei from the Departments of Computer Sciences, Spanish, Marketing, International Business, Multimedia Design, and Mechanic Engineering. They were three groups of listening proficiency levels: the advanced, upper-intermediate and lower-intermediate/elementary levels. The findings of his study showed that the more proficient listeners used more planning strategies than the less proficient listeners and that the more proficient listeners were more attentive than the less proficient listeners. The study also found that the planning strategies of managing attention, directed and selective attention, and advanced organization were highly correlated with listening proficiency. Liu also found that more proficient listeners had better knowledge of the high level in the hierarchy of strategy use to contribute their comprehension, and they did not rely on translating from their first language into the target language. In other words, they were more able to deploy the top-down processing (e.g., elaboration), whereas the less-proficient listeners focused on unknown lexis or grammar and thus had difficulty using the higher order strategy. However, the use of the translation strategy did not differ significantly between less proficient listeners and more proficient listeners. In addition, more proficient listeners were more in control of their emotions and had desire to be better at utilizing strategies to clarify meaning while communicating with a native speaker of the language. However, less proficient listeners seemed to be anxious when faced with the difficulty of unfamiliar lexis, or they lack social strategies for asking about unclear meanings from their conversational peers. These research studies focused on kinds of listening strategies employed by more-proficient and less-proficient listeners.

\section{Methodology}

\subsection{Participants}

The data for the present study were gathered from a group of 92 (n) out of 120 (N) Iranian EFL freshman university students randomly selected from five classes at a university in south of Esfahan based on the sample size table developed by Krejcie and Morgan (1970).The learners were all females and majoring in Teaching English as a Foreign Language (TEFL) course. They were native speakers of Persian (Farsi) aged 18. These freshman university students were selected as participants of this study because they are at the beginners' level of tertiary education in which they need to be relatively competent in English language particularly in listening skills to ensure that they would be able to cope with the teaching and learning context at university level. Iranian students are limited to three hours learning English at schools in a week. They are not exposed to English outside the classrooms hence the researcher in this study utilized the Oxford Placement Test to identify learners' listening proficiency levels. The students were ranged into three levels: students who scored between 67 and 100 were considered as advanced (19) and those who scored between 34 and 66 were intermediate $(n=39)$ and those who scored between 0 and 33 were considered as lower-intermediate $(\mathrm{n}=34)$.

\subsection{Instruments}

The first instrument used in this study was the Oxford Placement Test developed by Allen (1992) to identify the students' English listening proficiency levels. The Oxford Placement Test is a highly effective instrument and a reliable means of grading students at all levels from lower-intermediate upwards, with a consistent record of predictive validity in the light of examination entry (Allen 1992). Edwards (2007) also added that this placement test has been designed to assess students' knowledge of not only the key language but also their receptive and productive skills. Second, the Listening Strategy Questionnaire which included 23 Likert-Scaled items of three categories 
(meta-cognitive, cognitive, and socio-affective listening strategies). It was mainly adapted from the listening strategy questionnaire developed by Vandergrift (Personal Conversation, cited in Archer 2002; Vandergrift, Goh, Mareschal, and Tafaghodatari, 2006; and Vandergrift, 1997). The items were modified in order to suit the Iranian students' learning context. The Listening Strategy Questionnaire was piloted prior to the actual data collection and the reliability Cronbach's Alpha was 0.857 .

\subsection{Data analysis}

The statistical analysis was conducted utilizing the Statistical Package for Social Sciences (SPSS) 16.0 for Windows. The descriptive statistics (Means and Standard deviations) were utilized to rank order the listening strategies from the most preferred to the least preferred categories. Then, analysis was made to see the relationship between listening proficiency levels and the strategies employed by Iranian EFL freshman university students.

Before measuring the relationship between variables, it was essential to test the normality of the data (Abd Rahim Md Nor, 2009). One-Sample Kolmogorov-Smirnov test was run to test whether the sample means followed a normal distribution. The results showed that the $p$-values of the variables were not significant at 0.05 . The data followed a normal distribution. Therefore, the researcher used the Pearson Correlation analysis to show whether there was a significant relationship between the two variables.

\section{Findings and Discussions}

\subsection{Descriptive Analysis of the Listening Strategies among three Different English Listening Proficiency Groups}

Table 1 indicates the descriptive statistics for listening strategies and students' use of individual strategies by category (meta-cognitive, cognitive, and socio-affective) for the three English listening proficiency levels. As can be seen in Table 1, the mean value for meta-cognitive strategies which let students learn through planning, monitoring, and evaluating was 3.66 at a standard deviation of 0.40 among advanced freshmen; followed by the intermediate freshmen $(\mathrm{M}=3.59 ; \mathrm{SD}=0.40)$ and the lower-intermediate freshmen $(\mathrm{M}=3.53 ; \mathrm{SD}=0.41)$. This implies that the Iranian EFL freshman university students of three different listening proficiency groups employ meta-cognitive strategies more frequently than cognitive and socio-affective strategies. It implies that the students try to think about the ways in which they can plan, make decisions, monitor, and evaluate their listening. The lower-intermediate and intermediate freshmen of this sample similar to advanced freshmen also employed meta-cognitive strategies more frequently than cognitive and socio-affective strategies. This shows that meta-cognitive strategies are important because they regulate and direct the language learning process (O'Malley and Chamot 1990). This concurs with O'Malley, Chamot, Stewner-Manzanares, Kupper, and Russo 's (1985) study, they believed that intermediate students were more able to use meta-cognitive strategies than cognitive and socio-affective strategies whereas Vandergrift (2003) found that the more proficient listeners were able to use meta-cognitive strategies more frequently than the less proficient listeners, and the variations in this type of strategy use had a statistically significant relation across the listening ability.

Meanwhile, for cognitive strategies that allow students to rehearse, organize, and infer, the findings in Table 1 shows that the mean was high $(\mathrm{M}=3.57$ and $\mathrm{SD}=0.34)$ among the advanced freshman students followed by the intermediate freshmen with the mean value of 3.47 and the standard deviation of 0.42 and 3.42 and 0.45 for the mean and standard deviation respectively for the lower- intermediate freshmen. This reveals that the freshman students tend to employ repetition, resourcing, note-taking, deduction, translation, inferencing, and elaboration to comprehend the listening texts. The use of these cognitive strategies helps students monitor learning materials and apply specific techniques to a listening task (O'Malley and Chamot, 1990). Similarly, according to Goh (1998), students try to think about the way information is processed and stored, taking suitable steps to regulate the cognitive processes and utilize cognitive strategies to contribute them to process, store, and recall new information. They also infer the meaning of difficult words to understand the text.

For Socio-affective strategies through which learners cooperate, ask questions, and self-talk; the values were high for the advanced $(\mathrm{M}=3.46$ and $\mathrm{SD}=0.40)$ followed by intermediate $(\mathrm{M}=3.43 ; \mathrm{SD}=0.69)$ and the lower-intermediate freshmen $(\mathrm{M}=3.37 ; \mathrm{SD}=0.50)$. This indicates that Iranian $\mathrm{EFL}$ freshman university students utilize socio-affective strategies along with other strategies to improve their listening. According to O'Malley and Chamot (1990), socio-affective strategies describe the techniques listeners use to cooperate with one another, to solve their listening problems, to verify understanding or to lower anxiety.

This finding also indicates that Iranian EFL freshman university students of relatively lower-intermediate and intermediate levels similar to advanced level employed listening strategies frequently and actively. It is worthy to mention that freshmen of this sample are able to plan to use both top-down and bottom-up processing and employ meta-cognitive strategies such as thinking about the learning process, planning strategies for learning, paying 
attention to the main points in the listening task, and paying attention to details in the listening task. According to O'Malley and Chamot (1990), such learners attempt to take control of their cognition in order to reach their goals. In general, learners who utilize strategies use a wide range of strategies frequently, while students who do not use many strategies employ a very limited range $(\mathrm{Li}, 2005)$. The findings of the present research study also revealed that the high frequently use of meta-cognitive strategies seemed to contradict the stereotypical descriptions of learners from Asian backgrounds who preferred rote (habitual repetitions) learning and language rules as stated by O'Malley and Chamot (1990).

\subsection{The Analysis of the relationship between Listening Strategy Use and Listening Proficiency Levels}

In order to determine whether there was a statistically meaningful relationship between the listening strategies employed by Iranian EFL freshman university students and their English listening proficiency levels, the Pearson Correlation was computed. Table 2 reveals the results of this correlational analysis.

The results in Table 2 indicate that there was a statistically significant positive medium correlation between listening proficiency and meta-cognitive $\left(\mathrm{r}=0.566, \mathrm{p}<0.05, \mathrm{r}^{2}=.31\right)$ and socio-affective strategies $\left(\mathrm{r}=0.464, \mathrm{p}<0.05, \mathrm{r}^{2}=.21\right)$ among advanced freshman students $(\mathrm{n}=19)$. The correlation coefficient of the listening proficiency and meta-cognitive and socio-affective listening strategies accounts for $31 \%$ and $21 \%$ of the variations respectively.

Among intermediate freshmen $(\mathrm{n}=39)$, there was a significant and positive relationship between the listening proficiency and socio-affective listening strategies with correlation coefficients (r) of 0.415 which was significant at the 0.01 level. Their percentages of variance being $\mathrm{r}^{2}=.16$. The correlation coefficient of the listening proficiency and socio-affective listening strategies accounts for $16 \%$ of the variation. This means that these learners try to apply some specific techniques while listening.

Among lower-intermediate freshmen $(\mathrm{n}=34)$, their listening proficiency levels positively correlated with both meta-cognitive $\left(r=0.433, p<0.05, r^{2}=.18\right)$ and cognitive strategies $\left(r=0.340, p=<0.05, r^{2}=.11\right)$. The correlation coefficients of the listening proficiency and meta-cognitive and cognitive listening strategies account for $18 \%$ and $11 \%$ of the variation respectively.

In general, Table 2 shows that there was a significant positive relationship between the total listening strategies and the listening proficiency levels among advanced freshmen $\left(\mathrm{r}=0.579, \mathrm{p}<0.01, \mathrm{r}^{2}=.32\right)$, intermediate freshmen $\left(\mathrm{r}=0.321, \mathrm{p}<0.05, \mathrm{r}^{2}=.10\right)$, and lower-intermediate freshmen $\left(\mathrm{r}=385, \mathrm{p}<0.05, \mathrm{r}^{2}=.14\right)$. The correlation coefficients of the listening proficiency and total listening strategies among advanced, intermediate, and lower-intermediate freshmen account for $32 \%, 10 \%$, and $14 \%$ respectively.

Meanwhile, the strength of correlation between listening proficiency and meta-cognitive, cognitive and socio-affective strategies were also interpreted as medium according to the rule of thumb suggested by Cohen (1988) as: $r=0.10$ to 0.29 or $r=-0.10$ to -0.29 shows small correlation; $r=0.30$ to 0.49 or $r=-0.30$ to -0.49 indicates medium correlation; and $\mathrm{r}=0.50$ to 1.0 or $\mathrm{r}=-0.50$ to -1.0 reveals large correlation.

In addition, in an attempt to discover the linier relationship to show whether the strategies employed by Iranian EFL freshman university students was significantly associated with their listening proficiency levels (advance, intermediate, and lower-intermediate), scatter-plots were run as indicated in Figure 1 for advanced, intermediate, and lower-intermediate freshman groups. Listening proficiency scores were designated on the axis $(\mathrm{Y})$ and the total listening strategy scores on the axis (X).

Figure 1 shows that high scores on listening proficiency scores among advanced (A), intermediate (B), and lower-intermediate $(\mathrm{C})$ freshmen corresponding to high scores on listening strategies. This demonstrates that the patterns of the overall scores are nearly close to a straight line. It shows a linear association between the strategies employed by Iranian EFL freshman university students and their listening proficiency levels. Therefore, the current research statistically indicated that the higher the student's EFL listening proficiency level, the more frequent use of EFL listening strategies, and the lower the student's EFL listening proficiency level, the less frequent use of EFL listening strategies. This shows that the high and low proficient EFL freshman students reported the use of the strategies which were sufficient to them.

\section{Implications}

The findings of this study have practical implications for both lecturers who expect their students to be good English language listeners and Iranian EFL freshman university students who intend to improve and develop their listening skills while learning a new language in Iran. The high frequent use of meta-cognitive strategies among Iranian EFL freshman university students in this study appears to prove that meta-cognitive strategies are vital for improving their language learning in general and their listening skills in particular. Similarly, Goh (2000) stated that by increasing the students' knowledge of meta-cognitive strategies, listeners become more active in dealing with 
listening difficulties instead of simply accepting their problems. The meta-cognitive process involves a listener in a sequence of conscious actions such as analysis of the listening task requirements, activation of appropriate listening processes, making predictions of the task, monitoring and evaluating (Liu, 2008). Therefore, students should be able to employ meta-cognitive strategies to match their own learning process through planning their learning, monitoring, organizing, setting goals and objectives, considering the purpose, evaluating and help to look for practice opportunities (Oxford 1990, p.136). Thus, students should be taught to employ selective attention to get main ideas, taking notes, paying attention to linguistic markers that signal main ideas, details, and discourse structure in oral texts (O'Malley and Chamot, 1990). Generally, lecturers should make their students aware of using listening strategies. More importantly, lecturers should encourage their students of different listening proficiency levels to utilize listening strategies which are essential in their learning process in general and listening process in particular to develop their listening skills while learning a new language. It is also the lecturers' role to provide learners with the use of listening strategies in their teaching. The students need to be trained how to use specific strategies to improve their listening skills.

\section{Conclusion}

This study aimed to find out the strategies employed by Iranian EFL freshman university students and explore whether there was a relationship between the strategies employed by Iranian EFL freshman university students while listening to a spoken text and their listening proficiency levels. Based on the findings of this study, it may be concluded that Iranian EFL freshman university students of three different groups (advanced, intermediate, and lower-intermediate) are able to employ meta-cognitive strategies more frequently and actively followed by cognitive and socio-affective listening strategies. In other words, these freshmen are able to employ a great number of different listening strategies to comprehend a listening text. They are able to plan and use their top-down and bottom-up processing skills for learning in general and for listening in particular (Vandergrift 1997; National Capital Language Resource Center 2003, 2004). As the findings of this study indicated that there was a positive relationship between listening proficiency and listening strategies employed by them; these skills should be developed and inculcated as early as possible in the teaching and learning processes for university learners to ensure that they will succeed at tertiary education. Although this study may be limited by the instrument employed as it was adapted to the Iranian context, it may be replicated in other contexts where English is acquired or learned as a second language. Findings as such would definitely be of added knowledge towards an understanding of language learning strategies in general and listening strategies in particular.

\section{References}

Abd Rahim Md Nor. (2009). Statistical methods in research, Prentice Hall, Pearson Malaysia Sdn. Bhd.

Allen, D. (1992). Oxford placement test. Oxford: Oxford University Press.

Archer, C. G. (2002). The effect of language learning strategy instruction on listening comprehension proficiency and strategy use of learners of German as a Foreign Language. Online Master's thesis. University of Alberta.

Byrnes, H. (1984). The role of listening comprehension: A theoretical base. Foreign Language Annals, 17(4), 317-329.

Cohen, J. (1988). Statistical power analysis for the behavioral sciences. Hillsdale, NJ: Erlbaum.

Edwards, L. (2007). Solutions placement test elementary to intermediate: Oxford Exam Support. Oxford University Press, [Online] Available: www.oup.com/pdf/elt/cz/solutionsplacementtest, (20 Sept 2009).

Goh, C. C. (1998). How ESL learners with different listening abilities use comprehension strategies and tactics. Language Teaching Research 2 (2), 124-147.

Goh, C. C. M. (2000). A cognitive perspective on language learners' listening comprehension problems. System 28 (1), 55-57.

Goh, C. C. M. (2002). Teaching listening in the language classroom. SEAMEO Regional Language Centre, Singapore.. (Portuguese translation, 2003: O Ensino Da Compreensão Aulas De Idiomas).

Krejcie, R. V. and Morgan, D. W. (1970). Determining sample size for research activities. Educational and Psychological Measurement, 30, 607-610.

Li, A. (2005). A look at Chinese ESL students' use of learning strategies in relation to their English language proficiency, gender and perceived language difficulties-A quantitative study, Supporting Independent English Language Learning in the 21st Century: Proceedings of the Independent learning Association Conference Inaugural. Auckland: Manukau Institute of Technology. 
Liu, H. J. (2008). A study of the interrelationship between listening strategy use, listening proficiency levels, and learning style. RARECLS, 5, 84-104.

Mendelsohn, D. (1994). Learning to listen: A strategy-based approach for the second-language learner. San Diego, CA: Dominie Press.

Murphy, J M. (1985). An investigation into the listening strategies of ESL college students. ERIC Document Reproduction Service No. ED 278275.

Nagle, S. J., \& Sanders, S. L. (1986). Comprehension theory and second language pedagogy. TESOL Quarterly, 20(1), 9-26.

National Capital Language Resource Center. (2003, 2004). Teaching listening, strategies for developing skills. The National Capital Language Resource Center, Washington, DC [Online] Available: http://www.nclrc.org/essentials/listening/stratlisten.htm (17 Sept 2009).

O'Malley, J. M., A. U. Chamot, G. Stewner-Manzanares, L. Kupper, and R. Russo. (1985). Learning strategies used by lower-intermediate and intermediate ESL students. Language Learning 35:21-46.

O'Malley, J. M., Chamot, A. U., \& Kupper, L. (1989). Listening comprehension strategies in second language acquisition. Applied Linguistics, 10 (4), 418-437.

O'Malley, M. J., and Chamot, A. U. (1990). Learning strategies in second language acquisition. England: Cambridge University Press.

Oxford, R. L. (1990). Language learning strategies: What every teacher should know. New York: Newbury House Harper Collins.

Oxford, R. L. (1993). Research update on teaching L2 listening. System, 21(2), 205-211.

Richard, J. C. (1983). Listening comprehension: Approach, design, procedure. TESOL Quarterly, 17 (2), 219-240.

Scarcella, R. C., and Oxford. R. 1. (1992). The tapestry of language learning: The individual in the communicative classroom. Boston, MA: Heinle \& Heinle.

Vandergrift, L. (1996). Listening strategies of Core French high school students. Canadian Modern Language Review, 52 (2), 200-223.

Vandergrift, L. (1997). The comprehension strategies of second language (French) listeners: A descriptive study. Foreign Language Annals, 30, 387-409.

Vandergrift, L. (2003). Orchestrating strategy use: Toward a model of the skilled second language listener. Language Learning, 53 (3), 463-496.

Vandergrift, L., Goh, C., Mareschal, C. \& Tafaghodatari, M.H. (2006). The meta-cognitive awareness listening questionnaire (MALQ): development and validation. Language Learning, 56(3), 431-462.

Young, M. Y. C. (1997). A serial ordering of listening comprehension strategies used by advanced ESL learners in Hong Kong. Asian Journal of English Language Teaching, 1, 35-53.

Table 1. Descriptive Statistics for Listening Strategies by Category

\begin{tabular}{|c|c|c|c|c|}
\hline Listening Proficiency Levels & Listening Strategies & Mean & SD & N \\
\hline \multirow{3}{*}{ Advanced } & Meta-Cognitive & 3.66 & 0.40 & \multirow{3}{*}{19} \\
\cline { 2 - 4 } & Cognitive & 3.57 & 0.34 & \\
\cline { 2 - 4 } & Socio-Affective & 3.46 & 0.40 & \\
\hline \multirow{3}{*}{ Intermediate } & Meta-Cognitive & 3.59 & 0.40 & \multirow{3}{*}{39} \\
\cline { 2 - 4 } & Cognitive & 3.47 & 0.42 & \\
\cline { 2 - 4 } & Socio-Affective & 3.43 & 0.69 & \\
\hline \multirow{3}{*}{ Lower-Intermediate } & Meta-Cognitive & 3.53 & 0.41 & \multirow{3}{*}{34} \\
\cline { 2 - 4 } & Cognitive & 3.42 & 0.45 & \\
\cline { 2 - 4 } & Socio-Affective & 3.37 & 0.50 & \\
\hline
\end{tabular}

Note: $\mathrm{SD}=$ Standard Deviation; $\mathrm{N}=$ Number of freshmen 
Table 2. Pearson Correlation Matrix

\begin{tabular}{|c|c|c|c|c|c|}
\hline $\begin{array}{c}\text { Listening Proficiency Levels \& } \\
\text { Scores }\end{array}$ & Listening Strategy Use & $\begin{array}{c}\text { Pearson Correlation } \\
\text { (r) }\end{array}$ & $\mathbf{R}^{2}$ & Sig. & $\mathbf{N}$ \\
\hline \multirow{12}{*}{$\begin{array}{c}\text { Advanced } \\
\text { Mean }=79.21 \\
\text { SD }=7.09\end{array}$} & Meta-cognitive & $0.566^{*}$ & $31.36 \%$ & 0.011 & \multirow{12}{*}{19} \\
\hline & Cognitive & 0.448 & $19.36 \%$ & 0.054 & \\
\hline & Socio-affective & $0.464^{*}$ & $21.16 \%$ & 0.045 & \\
\hline & $\begin{array}{l}\text { Total listening } \\
\text { Strategies }\end{array}$ & $0.579 * *$ & $32.49 \%$ & 0.009 & \\
\hline & Meta-cognitive & 0.049 & 0 & 0.768 & \\
\hline & Cognitive & 0.145 & $01.96 \%$ & 0.379 & \\
\hline & Socio-affective & $0.415^{* *}$ & $16.81 \%$ & 0.009 & \\
\hline & $\begin{array}{l}\text { Total listening } \\
\text { Strategies }\end{array}$ & $0.321^{*}$ & $10.24 \%$ & 0.046 & \\
\hline & Meta-cognitive & $0.433^{*}$ & $18.49 \%$ & 0.011 & \\
\hline & Cognitive & $0.340^{*}$ & $11.56 \%$ & 0.049 & \\
\hline & Socio-affective & 0.197 & $03.61 \%$ & 0.264 & \\
\hline & $\begin{array}{l}\text { Total listening } \\
\text { Strategies }\end{array}$ & $0.385^{*}$ & $14.44 \%$ & 0.024 & \\
\hline
\end{tabular}

*. Correlation is significant at the 0.05 level (2-tailed).

**. Correlation is significant at the 0.01 level (2-tailed).

Note: $\mathrm{N}=$ Number of freshmen
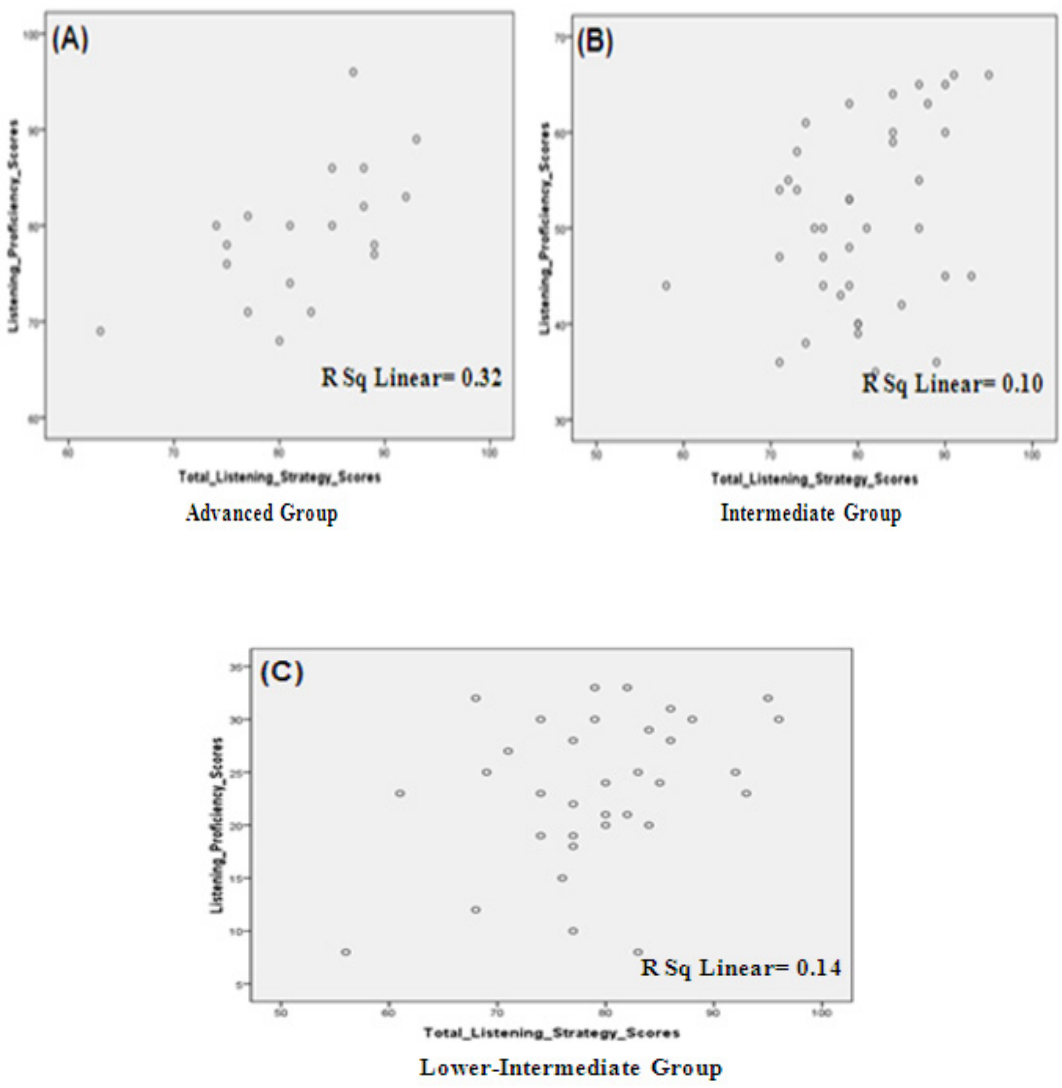

Figure 1. Scatter-plots for Correlation between Listening proficiency levels and Listening Strategy Use among Advanced, Intermediate, and Lower-Intermediate 